\title{
Uji Efek Antiinflamasi Ektrak Etanol 70\% Daun Leunca (Solanum Nigrum Linn) Terhadap Tikus Putih (Rattus Norvegicus Linn)
}

\author{
Rabima*, Immanuelly Sirait \\ Fakultas Farmasi, Universitas 17 Agustus 1945 Jakarta \\ *Email Korespodensi : Rabima86@gmail.com
}

(Submit 15/03/2019, Revisi 05/09/2019, Diterima 20/12/2019)

\begin{abstract}
Abstrak
Inflamasi adalah suatu respon protektif lokal yang ditimbulkan oleh cedera atau kerusakan jaringan yang berfungsi menghancurkan, mengurangi, atau mengurung (sekuestrasi) jaringan yang cedera ataupun agen penyebab cidera. Tanaman Leunca mengandung senyawa flavonoid yang berkhasiat sebagai antiinflamasi. Penelitian ini bertujuan untuk membuktikan efek antiinflamasi ekstrak etanol $70 \%$ daun leunca (Solanum nigrum Linn) terhadap edema telapak kaki tikus putih jantan galur Sprague dawley. Subjek yang digunakan sebanyak 25 ekor dibagi menjadi 5 kelompok, yang terdiri dari Kontrol Negatif (Na CMC 0,5\%), Kontrol Positif (Natrium Diklofenak 13,5 $\mathrm{mg} / \mathrm{kg} \mathrm{BB}$ ), dan kelompok perlakuan dengan dosis $250 \mathrm{mg} / \mathrm{kg} \mathrm{BB}, 350 \mathrm{mg} / \mathrm{kg} \mathrm{BB}, 450$ $\mathrm{mg} / \mathrm{kg}$ BB diberikan secara oral. Induksi dilakukan menggunakan karagenan 1\% sebanyak 0,1 ml secara sublantar. Pengukuran dilakukan tiap 60 menit selama 6 jam setelah penyuntikan karagenan menggunakan plestimometer. Kemudian dihitung persen inhibisi radang. Data yang diperoleh kemudian dianalisis menggunakan uji statistik one-way anova dilanjutkan dengan uji Least Significance Difference dengan tingkat kepercayaan 95\%. Dari presentasi inhibisi rata - rata dilihat bahwa presentase $\mathrm{Na}$. Diklofenak sebagai kontrol positif memiliki presentasi tertinggi sebesar $33,31 \%$, dosis $1(250 \mathrm{mg} / \mathrm{kg} \mathrm{BB})$ memiliki presentase inhibisi sebesar $18,6 \%$, dosis $2(350 \mathrm{mg} / \mathrm{kg}$ memiliki presentase inhibisi terbesar kedua dari kontrol positif sebesar $31,87 \%$, dan dosis $3(450 \mathrm{mg} / \mathrm{kg} \mathrm{BB})$ memiliki presentase inhibisi sebesar 12,075\%. Hasil uji statistik memperlihatkan bahwa terdapat perbedaan yang signifikan antar kelompok perlakuan $(P<0,05)$. Hasil penelitian menunjukan bahwa ektrak etanol $70 \%$ daun leunca dapat menurunkan volume udem pada kaki tikus yang diinduksikan dengan karagenan $1 \%$, dengan persen inhibisi radang tertinggi adalah pada dosis 2 (350 mg/kg BB).
\end{abstract}

Kata kunci: Antiinflamasi, Daun Leunca (Solanum nigrum Linn), Natrium Diklofenak, tikus putih

\section{Outline}

- Pendahuluan

- Metode

- Hasil dan Pembahasan

- Kesimpulan

- Saran

- Daftar Pustaka 


\section{Pendahuluan}

Indonesia merupakan negara tropis yang memiliki keanekaragaman hayati terbesar (mega biodiversitas) di dunia, ditemukan kurang lebih 30.000 dari 40.000 jenis tumbuhan di dunia. Tanaman tersebut sering dijadikan obat tradisional alternatif sebagai peran menggantikan obat - obatan modern ${ }^{1}$. Tanaman Leunca mengandung senyawa golongan alkaloid, flavonoid, saponin dan tanin ${ }^{2}$. Senyawa yang terdapat dalam daun leunca berkhasiat sebagai antiinflamasi adalah golongan flavonoid.

Inflamasi adalah proses yang kompleks, yang sering dikaitkan dengan rasa sakit dan melibatkan kejadian seperti peningkatan permeabilitas pembuluh darah, peningkatan denaturasi protein dan perubahan membran ${ }^{3}$. Inflamasi merupakan reaksi lokal pada jaringan vaskular terhadap cedera yang ditandai seperti rubor (kemerahan), kalor (panas), dolor (nyeri) dan turgor (pembengkakan) ${ }^{4}$.

\section{Metode}

Penelitian ini dilaksanakan selama bulan Mei 2017 - Juni 2017 di Laboratorium Farmakologi Fakultas Farmasi Universitas 17 agustus 1945.

\section{A. Alat dan Bahan}

Alat yang digunakan adalah plestismometer, neraca analitik, oral sonde tikus, lumpang dan alu, rotary evaporator, beker glass dan batang pengaduk.

Bahan yang digunakan adalah daun leunca, etanol $70 \%$, karagenan 1\%, Natrium Diklofenak, CMC, Nacl, tikus putih jantan.

\section{B. Pembuatan Simplisia}

Daun Leunca dibersihkan dari kotoran, kemudian dikeringkan dengan cara diangin anginkan. Daun leunca yang sudah kering dihaluskan sampai menjadi serbuk.

\section{Pembuatan Ekstrak}

Sebanyak 600 gram serbuk kering daun leunca diekstrak dengan cara di maserasi menggunkan pelarut etanol $70 \%$. Ditempatkan di dalam botol coklat selama 1x24 jam selama 3 hari. Filtrat yan didapat lalu diuapkan dengan rotary evaporator pada suhu $40^{\circ}$ dan dilanjutkan dengan waterbath sampai menjadi ekstrak yang kental.

\section{Pengujian Efek Antiinflamasi}

Tikus putih jantan galur Sprague dawley dipuasakan kurang lebih 18 jam namun tetap diberikan air minum. Yang berjumlah 25 ekor dibagi dalam 5 kelompok perlakuan yang masing - masing terdiri dari 5 ekor. Pembagian kelompok perlakuan, yaitu :

Kontrol Negatif : CMC 0,5\% $2 \mathrm{ml} / 200 \mathrm{grBB}$

Kontrol Positif : Na. Diklofenak 13,5 mg/KgBB

Kelompok Dosis 1 : Daun Leunca $250 \mathrm{mg} / \mathrm{KgBB}$

Kelompok Dosis 2 : Daun Leunca $350 \mathrm{mg} / \mathrm{KgBB}$

Kelompok Dosis 3 : Daun Leunca $450 \mathrm{mg} / \mathrm{KgBB}$

Enam puluh menit setelah pemberian obat uji atau larutan kontrol, disuntikkan larutan karagenan $1 \%$ pada telapak kaki kiri tikus. Penyuntikan karagenan dilakukan secara subplantar. Enam puluh menit kemudian volume kaki yang disuntik karagenan diukur 
pada alat (pletismometer air raksa) dengan cara mencelupkan telapak kaki kiri tikus ke dalam alat pletismometer air raksa sampai tanda spidol dan dicatat. Pengukuran dilakukan tiap 60 menit selama 6 jam setelah penyuntikan karagenan.

\section{E. Analisa Data}

Data yang diperoleh kemudian diuji dengan menggunakan uji normalitas metode Shapiro-Wilk dan dilanjutkan dengan uji homogenitas (Test of Homogenity of Variances ) dengan metode Levene. Jika hasil distribusi yang normal dan homogen, maka dilanjutkan dengan uji Analysis of Variance (ANOVA) satu arah, bila ada perbedaan bermakna dilanjutkan dengan uji perbandingan berganda menggunakan metode LSD (Least Significant Different). Pengelohan data dengan Statistical Package for the Social Science (SPSS) ${ }^{2}$.

\section{Hasil dan Pembahasan}

\section{A. Hasil Ekstrak Daun Leunca}

Pengujian parameter ekstrak yang digunakan meliputi uji organoleptis, skrining fitokimia dan susut pengeringan. Hasil organoleptis menunjukan bentuk ekstrak kental, warna hijau kehitaman, bau khas. Hasil dari skrining fitokimia daun leunca terdapat alkaloid, flavanoid, fenol, saponin, tanin, streoid, triterpenoid. Susut pengeringan dengan hasil $13,08 \%$. Daun leunca dibuat dalam bentuk ekstrak hal ini bertujuan agar zat yang terdapat dalam simplisia mempunyai kadar yang tinggi dan memudahkan dalam mengatur dosis.

Dari presentasi inhibisi rata - rata (Lampiran 1) dilihat bahwa presentase Na. Diklofenak sebagai kontrol positif memiliki presentasi tertinggi sebesar $33,31 \%$, dosis $1(250 \mathrm{mg} / \mathrm{kg}$ BB) memiliki presentase inhibisi sebesar $18,6 \%$, dosis $2(350 \mathrm{mg} / \mathrm{kg} / \mathrm{BB}$ memiliki presentase inhibisi terbesar kedua dari kontrol positif sebesar $31,87 \%$, dan dosis 3 $(450 \mathrm{mg} / \mathrm{kg} \mathrm{BB})$ memiliki presentase inhibisi sebesar 12,075\%. Dan dari presentase inhibisi pun terlihat bahwa dosis $350 \mathrm{mg} / \mathrm{kg}$ BB memiliki presentase penghambatan yang paling baik jika dibandingkan dengan dosis $250 \mathrm{mg} / \mathrm{kg}$ BB dan $450 \mathrm{mg} / \mathrm{kg} \mathrm{BB}$. Semakin besar presentase inhibisi maka semakin baik penghambatan udemnya.

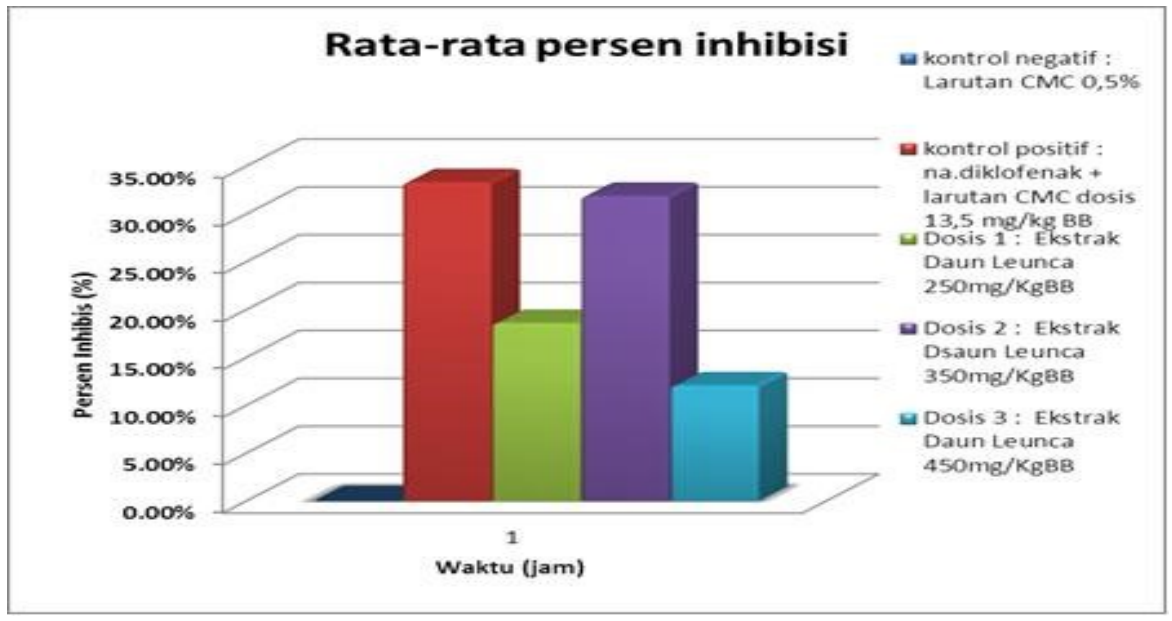

Gambar 1. Persen Inhibisi

Hasil yang diperoleh dari persentasi udem selanjutnya dianalisa dengan uji ANOVA untuk melihat bermakna atau tidak perbedaan dari masing-masing kelompok uji. Dalam 
uji ANOVA harus memenuhi persyaratan seperti normalitas (Shapiro-wilk) dan homogenitas (Levene statistic). Uji normalitas dilakukan untuk melihat distribusi data persen inhibisi udem telapak kaki tikus pada jam ke-1 sampai jam ke-6. Hasil uji normalitas menunjukkan nilai sig pada kelompok kontrol positif sebesar 0,372, KEL 1 nilai signya sebesar 0,912, KEL 2 nilai signya sebesar 0,114, dan KEL 3 nilai signya sebesar 0,135 . Karena dari hasil nilai sig yang diperoleh menunjukkan kontrol posif dan semua semua kelompok 1,2, dan 3 lebih besar dari 0,05 maka dapat disimpulkan bahwa data persen inibisi terdistribusi normal dengan kriteria uji (sig $>0,05$ ) maka Ho diterima. Dilanjutkan dengan uji homogenitas menggunakan metode Levene dengan syarat nilai sig $>0,05$.

Uji homogenitas variannya untuk melihat data persen inhibisi apakah homogen atau tidak. Setelah diperoleh table uji homogenitas varia, menunjukkan bahwa semua kelompok uji homogen dengan nilai sig sebesar 0,622, maka Ho diterima. Jika nilai homogenitasnya terpenuhi maka dilanjutkan dengan uji ANOVA untuk mengetahui adanya perbedaan yang bermakna dari volume telapak kaki tikus tiap perlakuan. Berdasarkan table ANOVA satu arah didapatkan nilai signifikansi sebesar 0,034 dengan syarat nilai sig $>0,05$, jika nilai $P$ lebih besar dari 0,05 maka Ho diterima, dan sebaliknya.

Berdasarkan nilai signifikansi yang didapatkan, disimpulkan bahwa Ho ditolak. Dengan demikian data menunjukan adanya perbedaan pada tiap perlakuan. Maka dapat dilanjutkan dengan uji perbandingan berganda LSD (Least Significant Different) untuk melihat letak perbedaan. Data persen inhibisi yang diperoleh dari uji ANOVA satu arah menunjukan adanya perbedaan pada tiap kelompok perlakuan, maka dilanjutkan dengan uji perbandingan data persen inhibisi antara pasangan kelompok perlakuan.

Tabel uji perbandingan berganda memperlihatkan adanya perbedaan data persen inhibisi KKP tidak terdapat perbedaan signigfikan dengan KEL 1, KKP juga tidak ada perbandingan bermakna dngan KEL 2, KKP memiliki perbandinan bermakna dengan KEL 3 sig $(<0.05)$. Data persen inhibisi KEL 1 tidak ada perbandingan bermakna dengan KKP,

memiliki perbandingan bermakna dengan KEL 2 dan tidak memiliki perbandingan bermakana dengan KEL 3. Data Inhibisi KEL 2 tidak ada perbandingan bermakna dari $\mathrm{KKP}$, memiliki perbandingan bermakna dengan KEL 1, dan memiliki perbandingan bermakna dengan KEL 3 karena KEL 1 dan KEL 3 memiliki sig $(<0.05)$. KEL 3 terdapat perbandingan bermakna dengan KKP, tidak memiliki perbandingan bermakna dengan KEL 1, dan memiliki perbandingan bermakna dengan KEL 2 sig $(<0.05)$.

Pada KEL 2 dengan dosis $350 \mathrm{mg} / \mathrm{kg}$ BB memiliki efek antiinflamasi lebih kuat dari dosis $250 \mathrm{mg} / \mathrm{kg}$ BB dan $450 \mathrm{mg} / \mathrm{kg}$ BB karena presentase inhibisi KEL 2 tidak jauh dari KKP. Seharusnya dengan meningkatnya dosis maka aktivitas antiinflamasinya juga akan menunjukan peningkatan, akan tetapi pada ekstrak etanol $70 \%$ daun leunca (Solanum nigrum Liin) memiliki aktivitas yang sebaliknya.

Hal tersebut bisa terjadi karena pengukuran dengan menggunakan plestismometer kejelasan akurasi pada saat pembacaan skala. Hal lainnya bisa terjadi memang pada KEL 2 meningkat karena faktor efisien suatu obat memberikan efek farmakologi pada kisaran dosis tertentu. Pada KEL 3 kecenderungan inhibisi menurun karena penurunan 
efektivitas yang menyebabkan terjadinya kelebihan dosis yang menimbulkan efek toksis pada hewan uji yang menyebabkan produk prostaglandin pada hewan uji meningkat sehingga obat tidak menimbulkan efek peningkatan walaupun dosis di tambah ${ }^{5}$.

\section{Kesimpulan}

Berdasarkan hasil penelitian, dapat disimpulkan bahwa Daun Leunca (Solanum nigrum Linn) mempunyai efek antiinflamasi tertinggi pada dosis 2 (350 mg/kg BB) dengan persen radang inhibisi sebesar $31,87 \%$. Efektivitas daun leunca (Solanum nigrum Linn) sebagai antiinflamasi lebih kecil dibanding dengan kontrol positif (Natrium Diklofenak 13 $\mathrm{mg} / \mathrm{kg} \mathrm{BB}$ ) dengan persen inhibisi radang $33,32 \%$.

\section{Saran}

Daun leunca (Solanum nigrum Linn ) dapat dilakukan penelitian uji efek antiinflamasi dengan menggunakan pelarut atau fraksinasi yang berbeda.

\section{Daftar Pustaka}

1. Corwin, Elizabeth J, 2008, Handbook of pathophysiology 3th edition. Philadelphia, Lippincort Williams \& Wilkins. 138-143.

2. Dalimarta, S. 2008. Atlas Tumbuhan Obat Indonesia. Jilid kelima. Jakarta : Pustaka Bunda. Hal.100-103.

3. Leelaprakash, G., S.Mohan D. 2011. Invitro Anti-Inflammatory Activity of Methanol Extract Of Enicostemma Axillare.

4. International Journal of Drug Development \& Research3(3); Pages 189196. Pronob, G., dan Islam, M. 2012. Phytochemical Screening of Solanum nigrum L. And S. Myriacantus Dunal from Districts of Upper Assam, India. IOSR Journal of Pharmacy 2(3): 455 - 459.

5. Santoso, S. 2004. Menguasai Statistik di Era Informasi. Gramedia, Jakarta: hal $213-223$

6. Tjay, T., Rahardja, K. 2010. Obat-Obat Penting. Jakarta: Elex Media Komputindo. Hal 63, 65, 66 